DOI 10.4467/2543733XSSB.17.009.9984

IRENA STAWOWY-KAWKA

Uniwersytet Jagielloński

\title{
ROK 1947 W RELACJACH BULGARSKO-JUGOSLOWIAŃSKICH W KONTEKŚCIE POLITYKI STALINA I SYTUACJI MIĘDZYNARODOWEJ
}

\author{
1947 in Bulgarian-Yugoslav Relations \\ in the Context of Stalin's Policy and International Situation \\ Summary
}

The Bulgarian-Yugoslav relations in 1947, built by the Soviet Union, were part of the concept of strengthening Soviet influence in Central and Eastern Europe and in the Balkans. Stalin knew very well about the contacts between Tito and Dimitrov, about their negotiations in Bled and about signing the agreement in Euxinograd, and Stalin knew exactly and controlled all the actions of the Yugoslav and Bulgarian leaders.

Although the Yugoslav Marshal Josip Broz-Tito, rising to become a main leader in the Balkan region, had a different attitude to many political issues than Stalin, and at the time of a sharpened division into East and West their ideas regarding foreign policy - Balkan - were different. At that time Tito's foreign policy was a welcome excuse to tighten Moscow's cooperation with Yugoslavia and thereby exacerbate Soviet control over other countries, including Bulgaria. An important element of this policy was the creation of the Cominform and opposing the Marshall Plan.

To illustrate this thesis, the situation in 1947 was analysed, which concerned the Bulgarian-Yugoslav relations.

Keywords: Bulgarian-Yugoslav federation, Macedonian problem, Cominform, Bled, Tito's policy, Dimitrov

Słowa kluczowe: federacja bułgarsko-jugosłowiańska, problem macedoński, Kominform, Bled, polityka Tity, Dymitrow

Zagadnienie relacji bułgarsko-jugosłowiańskich w 1947 r. do dzisiaj budzi kontrowersje. Kontakty między tymi państwami były bowiem uwarunkowane ścieraniem się na Bałkanach interesów mocarstw, z jednej strony Sowietów, z drugiej - Wielkiej Brytanii i USA. W arty- 
kule przedstawiono podmiotowość państw bałkańskich - Bułgarii i Jugosławii - oraz z jednej strony stopień akceptowania przez Sowietów ich politycznej samodzielności, a z drugiej moment, w którym w zależności od swoich interesów, z całą stanowczością decydowali się na ingerencję. W 1947 r. podmiotowość obu państw najlepiej widoczna jest przez pryzmat kontaktów między nimi. W polskiej literaturze przedmiotu najważniejszymi pracami poświęconymi temu zagadnieniu są: artykuł pt. „Apogeum” zbliżenia poludniowostowiańskiego po II wojnie światowej. Porozumienie Bułgarii i Jugosławii w 1947 r. (1 sierpnia w Bled oraz 27 listopada w Ewksinogradzie) pióra Elżbiety Znamierowskiej-Rakk oraz monografia tej samej autorki Federacja Stowian poludniowych w polityce Butgarii po II wojnie światowej. Korzenie. Próby realizacji. Upadek. Ważna jest także praca Wiesława Walkiewicza, Stosunki bułgarsko-jugostowiańskie 1941-1948. Uwarunkowania i implikacje1. Wskazać należy także opracowania badaczy bułgarskich, serbskich oraz interpretacje historyków zachodnich².

We wspomnianych publikacjach skupiono się przede wszystkim na prowadzonych w Bled negocjacjach bułgarsko-jugosłowiańskich - wraz z analizą ich przebiegu - przy czym za cezurę uznano rok 1947, będący apogeum dobrych relacji między Dymitrowem a Tito. Niemniej interpretacja, że przywódcy jugosłowiańscy i bułgarscy samodzielnie - bez dyrektyw Stalina - podejmowali decyzje polityczne budzi kontrowersje. Stalin dokładnie wiedział o rozmowach w Bled oraz o podpisaniu w Ewksinogradzie układu między Jugosławią a Bułgarią; były bowiem ważne dla jego koncepcji, by wzmocnić wpływy Sowietów w Europie Środkowo-Wschodniej i na Bałkanach, a wszelkie porozumienia obu przywódców: Tity i Dimitrowa w 1947 r., przyjęte bez wcześniejszej aprobaty Moskwy, Stalin potrafił kontrolować. Do końca 1947 r. Tito pozostawał wiernym sojusznikiem Stalina i tak nadal przez polityków Zachodu był postrzegany - jako oddany współpracownik Moskwy. Mimo iż jugosłowiański marszałek Josip Broz-Tito, wyrastający na czołowego przywódcę w regionie Bałkanów, w wielu kwestiach politycznych miał odmienne stanowisko niż Stalin, a w momencie zaostrzonego podziału na Wschód i Zachód ich koncepcje dotyczące polityki - bałkańskiej - były różne, to w tym czasie polityka zagraniczna Tity stanowiła pożądany pretekst do intensyfikacji współpracy Moskwy z Jugosławią i w rezultacie wzmocnienia kontroli państw pozostających w sowieckiej strefie wpływów, także Bułgarii.

W pracy wykorzystano przede wszystkim dokumentację z Narodowego Archiwum w Londynie (National Archives), Centralnego Archiwum Państwowego Republiki Bułgarii w Sofii (Centralen Dyrżawen Archiw na Republika Byłgarija) oraz Państwowego Archiwum Republiki Macedonii w Skopiu, (Državen Arhiv na Republika Makedonija) oraz

${ }^{1}$ E. Znamierowska-Rakk, „Apogeum” zbliżenia poludniowostowiańskiego po II wojnie światowej. Porozumienie Butgarii i Jugosławii w 1947 r. (1 sierpnia w Bled oraz 27 listopada w Ewksinogradzie), Dzieje Najnowsze 2005, nr 37/2, s. 55-84; Eadem, Federacja Stowian poludniowych w polityce Butgarii po II wojnie światowej. Korzenie. Próby realizacji. Upadek, Warszawa 2005; W. Walkiewicz, Stosunki butgarsko-jugostowiańskie 1941-1948. Uwarunkowania i implikacje, Warszawa 1988.

${ }^{2}$ W. Angełow, Chronika na edno nacionalno predatelstwo, Błagoewgrad 1999; M. Isusov, Stalin i Bytgarija, Sofia 1991; L. Panajotow, K. Paleszutski, D. Miczew, Makedonskijat wypros i bylgaro-jugoslawskite otnoszenija. Istorija, archeologija, kraeznanie, Sofija 1991; V. Jotevski, Nacionalnata afiranacija na Makedoncite vo Pirinskiot del na Makedonija 1944-1948, Skopje 1996; T. Čepreganov, Stavot na Velika Britanija kon prašanjeto na Makedonija i jugoslovensko-bulgarskata federacija, Skopje 1980; S. Nešović, Bledski sporazummi. TitoDimitrov (1947), Zagreb 1979; L.Ia. Gibianskii, The Soviet-Yugoslav Conflict and the Soviet Bloc, [w:] F. Gori, S. Pons, red., The Soviet Union and Europe in the Cold War, 1943-1953, Palgrave Macmillan UK, 1996, s. 222-231. 
zbiory drukowanych dokumentów: amerykańskich, bułgarskich i serbskich. Również opublikowane przez Leonida Ia. Gibianskiiego trzy ważne dokumenty z archiwów w Moskwie z 1946 i 1948 r., które rzucają nowe światło na wydarzenia w 1947 r. ${ }^{3}$

Rok 1946 był dla relacji bułgarsko-jugosłowiańskich bardzo ważny. Przyniósł bowiem szereg uzgodnień politycznych, które wskazywały na fakt, że zagadnienie tworzenia federacji bałkańskiej - wciąż aktualne - jest popierane zarówno przez Moskwę, jak i Bułgarię oraz że zostało zaakceptowane przez Jugosławię. Obawy USA i Wielkiej Brytanii, zwiększone przez projekty federacji bułgarsko-jugosłowiańskiej, obejmować też mogły, zdaniem anglosaskich polityków, dążenia Belgradu do uzyskania portu w Salonikach. Także Bułgarzy zawsze patrzyli na Saloniki jak na stolicę ,,wielkiej Macedonii”. W tym kontekście budziły niepokój przedstawiane przez Bułgarów żądania, by zwrócić im Trację Zachodnią. Co więcej, obawiano się, że ZSRS może poprzeć te ekspansjonistyczne pretensje południowych Słowian. Stworzenie szerszej niż tylko bułgarsko-jugosłowiańskiej federacji mogło odpowiadać aspiracjom strategicznym Moskwy. Przypominano o sowieckich dążeniach do rewizji konwencji dotyczącej Cieśnin Czarnomorskich ${ }^{4}$, czego wyrazem była nota w tej sprawie, wystosowana 8 sierpnia 1946 r. do Turcji oraz roszczenia terytorialne odnoszące się do wilajetów: Karsu, Ardahanu i Artvinu. Poważnie zaniepokojona koncepcjami federalistycznymi Turcja zaproponowała utworzenie przeciwstawnego bloku. Roszczenia, które Stalina wysunął wobec Turcji, dały asumpt do przypuszczeń, że wojna domowa w Grecji jest rezultatem skoordynowanego planu, potęgowanych faktem, że już w okresie międzywojennym kwestia macedońska wykorzystywana była przez Komintern, który w latach 1924-1935 przyjął ideę Macedonii niezależnej i zjednoczonej przez scalenie trzech części: jugosłowiańskiej, bułgarskiej i greckiej. Dla wywołania „ruchu rewolucyjnego”, który prowadziłby do integracji, utworzono wówczas Wewnętrzną Macedońską Rewolucyjną Organizację (Zjednoczoną) WMRO (Zjednoczona) $)^{5}$. Zatem prawdopodobne było, że Moskwa chce ów plan ponownie wykorzystać, zwłaszcza że znali go dobrze Georgi Dymitrow, który w latach 1934-1943 był sekretarzem generalnym Kominternu, i Josif Broz-Tito, w tym czasie czołowy działacz KPJ.

${ }^{3}$ Cold War International History Project, Bulletin 10, Washington 1998, red. L.Ia. Gibianskii, Dok. I, Soviet and Yugoslav Records of the Tito-Stalin Conversation of 27-28 May 1946, s. 119, 120, Dok. II Yugoslav Record of Conversation of I.V. Stalin and the Yugoslav Government Delegation Headed by J. Broz Tito, 27-28 May 1946, s. 120-127; Dok. III, Report of Milovan Djilas about a secret Soviet-Bulgarian-Yugoslav meeting 10 February 1948, s. 128-134. Dokument trzeci znany jest w trzech wersjach różniących się w szczegółach, ale nie w zasadniczych sprawach. Oprócz tego ujawnionego przez L.Ia. Gibianskiego czytelnik polski zna wersję przedstawioną w pracy Milovana Djilasa, Rozmowy ze Stalinem, rozdział pt. Rozczarowania, Warszawa 1991, s. 106-156 oraz bułgarską wersję: Razszifrowan stenografski zapis w beleżnik na W. Kołarow za sydyrżnieto i rezultastite ot prowedena sywetsko-jugoslawsko-byłgarska tajna sreszcza w Moskwa po iniciatiwa na J.W. Stalin sled izjawlenija na G. Dimitrow za ewentualno syzdawanje na Balkanska fedreracija ili Balkano-Dunawska konfrderacija, Moskwa 10, fewruari $1948 \mathrm{~g}$. w: Makedonskijat wypros w byłgaro-jugoslawskite otnoszenija (1944-1952 g.), dok. 185, Sofija 2004, s. 262-270.

${ }^{4}$ Rewizja konwencji z Montreux z 1936 r. uwzględniała interesy państw czarnomorskich, w tym kwestię ustanowienia turecko-sowieckiej obrony cieśnin. W ten sposób flota sowiecka mogłaby stacjonować w bazach Bosforu i Dardaneli.

${ }^{5}$ I. Stawowy-Kawka, Stosunek III Międzynarodówki i bałkańskich partii komunistycznych do problemu narodowego w Macedonii, Zeszyty Naukowe UJ, Seria Nauk Politycznych, 1985, z. 25, s. 61-80. 
W trakcie spotkania Stalina z Titą na Kremlu w dniach 27 i 28 maja 1946 r. wrócono do sprawy utworzenia federacji bułgarsko-jugosłowiańskiej, która bezpośrednio po zakończeniu wojny była szeroko dyskutowana przez ZSRS i partie komunistyczne: „Tito stwierdził, że taka federacja nic nie da. Stalin odparł: to musi być zrobione"6. Wówczas Tito, przeciwny tej koncepcji, argumentował, że w Bułgarii i Jugosławii różny jest układ sił realnie sprawujących władzę polityczną - podczas gdy w Jugosławii od 1945 r. rządzili wyłącznie komuniści, w Bułgarii w skład Frontu Ojczyźnianego oprócz komunistów wchodziły inne partie.

Jednak Stalin, uznając powyższe obawy za bezpodstawne, sugerował, by realizację projektu rozłożyć na etapy, z których pierwszym byłoby podpisanie paktu o przyjaźni i wzajemnej pomocy. Mołotow natomiast uważał, że trudność utworzenia takiej federacji może wynikać z faktu niepodpisania układu pokojowego z Bułgarią, która tym samym może być postrzegana jako wróg7. Mołotow powoływał się na sprzeciw Stanów Zjednoczonych i Wielkiej Brytanii z 10 lutego 1945 r. ${ }^{8}$ Znamienne, że Stalin, podkreślając doniosłość federacji, opowiadał się za „federacją podwójną”, co oznaczało równy w niej status Bułgarii i Jugosławii, natomiast Tito - przeciwny temu projektowi - miał wizję związku federacyjnego, w którym Bułgaria - obok Macedonii, Serbii, Czarnogóry, Bośni i Hercegowiny, Chorwacji i Słowenii - byłaby jedną z republik ${ }^{9}$.

Po rozmowach ze Stalinem, które delegacja bułgarska na czele z Dymitrowem przeprowadziła w Moskwie 6 czerwca 1946 r., między komunistycznymi partiami Jugosławii i Bułgarii doszło do porozumienia w kwestii macedońskiej. Na X (poszerzonym) plenum KC BPR(k) dnia 14 sierpnia 1946 r., w całości poświęconym problemowi macedońskiemu, przyjęto podyktowane przez Jugosławię warunki zjednoczenia dwu części Macedonii - Ludowej Republiki Macedonii oraz bułgarskiej Macedonii, często określanej przez samych Bułgarów Piryńskim Krajem lub Macedońskim Krajem, zgodnie z którymi postanowiono o włączeniu Macedonii Piryńskiej (bułgarskiej) do Ludowej Republiki Macedonii (dalej LRM) w zamian za oddanie Bułgarii niewielkich obszarów wokół Bosilegradu, Strumicy oraz kilku wsi nad Timokiem, należących dotąd do Serbii. Sugerować to mogło, że zjednoczenie dwóch części Macedonii, jugosłowiańskiej i bułgarskiej, zostało przesądzone. Jednocześnie widać było determinację Stalina, który zgodził się na przyjęcie wariantu jugosłowiańskiego tegoż zjednoczenia. Ze względu na wojnę domową w Grecji, tak w Wielkiej Brytanii jak i USA brano pod uwagę, że Stalin może zamierzać scalenie trzech ziem macedońskich.

\footnotetext{
${ }^{6}$ Cold War International..., [w:] Yugoslav Record of Conversation..., s. 120. Do sprawy federacji bułgarsko-jugosłowiańskiej Stalin i Tito powrócili ponownie podczas tego spotkania. Wówczas Stalin spytał: „Czy jesteś teraz za federacją z Bułgarią? Tito: Nie. Teraz nie jest czas na to, bo jeszcze definitywnie nie rozwiązaliśmy wielu rzeczy: partie burżuazyjne, monarchia i stanowisko Bułgarów na temat podpisania traktatu pokojowego". Ibidem, s. 122.

${ }^{7}$ Ibidem.

${ }^{8}$ FRUS 1945, vol. III, Yugoslav-Bulgarian Relations, Yalta February 10, 1945, s. 890. ...,państwo wrogie, którego status jest wciąż regulowany przez warunki zawieszenia broni, nie może wchodzić w specjalne układy traktatowe z innymi państwami, z którymi jest ono technicznie w stanie wojny - chyba że ma ono wyraźną zgodę wszystkich zwycięskich mocarstw, z którymi zawieszenie broni zostało podpisane". Szerzej na ten temat zob. I. Stawowy-Kawka, Powojenne koncepcje federacji jugostowiańsko-butgarskiej (1944-1948), Zeszyty Naukowe UJ. Seria Nauk Politycznych UJ, 1988, t. CMXXII, z. 34, s. 128 i nast.

${ }^{9}$ O uzgodnieniach tych szerzej zob. Z. Rutyna, Jugosławia na arenie międzynarodowej, Warszawa 1981, s. 277 i nast.
} 
Gdy na początku 1947 r. część Grecji znalazła się pod kontrolą DAG (Demokratyczna Armia Grecji gr. - DSE Dimokratikos Stratos Ellados), zagrożenie ekspansją komunistyczną było na tyle duże, że ambasador USA w Atenach w lutym 1947 r. ostrzegał sekretarza stanu Stanów Zjednoczonych, że jeśli Grecję zaleje komunizm, to Bliski Wschód i północna Afryka znajdą się w strefie wpływów sowieckich ${ }^{10}$.

W powstałej w ramach federacji jugosłowiańskiej Macedonii idea jej autonomii i zjednoczenia była tak popularna, że w latach 1946 i 1947 Tito musiał podjąć działania skierowane przeciwko powstającym żywiołowo grupom WMRO. Na posiedzeniu CK KPM (Komitet Centralny Komunistycznej Partii Macedonii) 8 maja 1947 r. stwierdzono, że „nie istnieje ogólna WMRO dla całej Macedonii, ale to nie oznacza, że nie może ona powstać, gdy nie podejmiemy odpowiednich środków" ${ }^{11}$. Obawy Tity dotyczyły ideałów starej WMRO, które przewidywały zjednoczenie Macedonii i utworzenie autonomicznego państwa, wówczas w ramach Turcji, aby w przyszłości uzyskać całkowitą wolność. Po drugiej wojnie światowej działania WMRO oznaczały niezależność od Jugosławii ${ }^{12}$.

Poselstwo Brytyjskie w Sztokholmie dnia 6 lutego 1947 r. raportowało do Londynu, że Rosjanie przedstawili rządowi bułgarskiemu i jugosłowiańskiemu plan, by na terytorium dwóch państw: Bułgarii i Jugosławii utworzyć jeszcze trzecie - Macedonię ${ }^{13}$. W przyszłości zaplanowano zaproszenie też Grecji, by ta scedowała część swego terytorium, włączając port w Salonikach, dzięki czemu Macedonia - będąca dotąd jedną z republik Jugosławii - miałaby dostęp do Morza Egejskiego. Przewidując, że Grecja będzie stawiać opór, nie wykluczono zastosowania środków przymusu ${ }^{14}$. Pogłoski te budziły niepokój tak w Wielkiej Brytanii, jak i w USA, gdyż trudno było wysondować rzeczywiste cele Stalina. W Londynie podkreślano, że takie rozwiązanie może stanowić zagrożenie dla Grecji, a tym samym dla interesów brytyjskich w basenie Morza Śródziemnego. W podobnym tonie utrzymane były doniesienia brytyjskiego ambasadora w Paryżu Alfreda Duff-Coopera, któremu Numanem Menemendżoglu, jego turecki odpowiednik, powiedział o zaniepokojeniu Turcji:

On ma obawy [Menemendżoglu - I. S.-K.], że Rosjanie wykorzystają greckich dysydentów w celu utworzenia nowego państwa macedońskiego z części oderwanej od Bułgarii, Jugosławii i Grecji wraz z Salonikami. Taki rozwój wydarzeń osłabiłby Grecję i odciął Turcję od Europy ${ }^{15}$.

${ }^{10}$ FRUS, 1947, vol. V, The Near East and Africa, s. 30. The Ambassador in Greece (MacVeagh) to the Secretary of State, Athens, February 20, s. 30.

${ }^{11}$ Arhiv na Makedonija (dalej AM) Skopie, f. CK KPM, k.1, a.e. 29, 1.3, Zapisnik br. 6, Zapisnik CK KPM na 8 V 1947 god.

${ }^{12}$ W 1946 r. aresztowany został Matodija Andonov-Čento i inni popularni działacze polityczni. Poddawali oni krytyce zasady działania centralistycznego państwa i propagowali ideę zjednoczenia Macedonii pod protektoratem USA i Wielkiej Brytanii, wzorem migracji macedońskiej w USA i Kanadzie, która wystosowała do sekretarza generalnego ONZ, dra Trygve Lie, „Memorandum”. W „Memorandum”, w którym powoływano się na słowa Williama E. Gladstone’a sprzed 70 lat „Macedonia dla Macedończyków”, czytamy: „Oznacza to geograficzną jedność trzech części Macedonii jako niezależnej jednostki politycznej, w której wszystkie narody mogą mieć równe prawa, obowiązki i możliwości”. FO 371/58615 Macedonian Political Organization of the USA and Canada, Central Committee.

${ }^{13}$ NA, FO 371/66 985 (R 2179/1296/67), Swedish report of Russian plan for a Macedonian State, British Legation Stockholm, 6th February 1947.

${ }^{14}$ Ibidem.

${ }^{15}$ NA, FO 371/66985, Copy of Despatch from Mr. Duff Cooper to Mr. Bevin, The British Embassy, Paris. 8th July 1947. 
Podkreślił z wielkim naciskiem, że osłabienie Grecji jest równoznaczne z osłabieniem Turcji. W dalszej części rozmowy Duff-Cooper wskazał, że dla Turków bezpośrednie zagrożenie jawi się jako bardzo realne ${ }^{16}$.

Dnia 21 lipca z Ambasady Brytyjskiej w Waszyngtonie przesłano do Departamentu Stanu dokument „Aide Memoire”, w którym wskazując na wcześniejsze wydarzenia oraz obecne niepokoje i aresztowania w Grecji, przypominano, iż Sowieci będą chcieli poszerzyć swoją strefę wpływów przez utworzenie państwa - Macedonii, co może się stać wskutek włączenia Macedonii Egejskiej do federacji (jugosłowiańsko-bułgarskiej lub jugosłowiańskiej) ${ }^{17}$. Podkreślano, iż brytyjskiemu ministrowi spraw zagranicznych, Ernestowi Bevinowi, zależy na zapobieżeniu, by kwestia Macedonii stała się kwestią praktyczną, czy nawet przedmiotem międzynarodowej dyskusji. Dlatego sugerował, by w przypadku podjęcia przez państwa bałkańskie jakichkolwiek kroków w kierunku utworzenia państwa macedońskiego, rząd Jej Królewskiej Mości i rząd USA, nie tracąc czasu, publicznie wyjaśniły, iż są świadome takiego ruchu i że są mu przeciwne ${ }^{18}$. W piśmie tym przypominano zamieszczone w „Rizospastis” wystąpienie greckiego lidera komunistycznego, Nikolasa Zachariadesa, iż celem komunistów jest „Wolna Grecja”, co opatrzono komentarzem: „która w praktyce może stać się »Wolną Macedonią«"19.

Takie niebezpieczeństwo widzieli także Anglicy, o czym donosili do państw Brytyjskiej Wspólnoty Narodów (Commonwealth of Nations) w telegramie z Ministerstwa Spraw Zagranicznych.

... uważamy, że możliwe jest, iż jugosłowiańska i bułgarska władza, przy pomocy Sowietów, wykorzystają współczesną sytuację destabilizacji i aresztowań w Grecji i utworzą jednostkę w ramach jugosłowiańskiej federacji lub we współpracy jugosłowiańsko-bułgarskiej powołają federację, by w ten sposób wrzucić w sowiecką orbitę wpływów region egejski ${ }^{20}$.

W dalszej części dokumentu przypomniano, że mimo jugosłowiańskich i bułgarskich starań - w myśl postanowień traktatu pokojowego w Paryżu z 10 lutego 1947 r., Jugosławia nie zyskała dostępu do Salonik, natomiast Alexandroupolis (buł. Dadeagacz) nie weszło do terytorium Bułgarii.

Z kolei Tito zaręczał Ralphowi Stevensonowi, byłemu ambasadorowi Wielkiej Brytanii, że pogłoski, jakoby Belgrad miał jakieś plany odnośnie do greckiej Macedonii, są całkowicie nieprawdziwe ${ }^{21}$. Znamienne, że Tito podobnych zapewnień nie złożył w Atenach, aczkolwiek Stevenson sugerował, by to uczynił22.

Wprawdzie w 1947 r. tworzenie federacji bałkańskiej tak w Sofii jak w Belgradzie nadal brano pod uwagę, niemniej ze względu na sytuację geopolityczną w Europie Środ-

${ }^{16}$ Ibidem.

${ }^{17}$ NA, FO 371/66 985, Copy of Aide Memoire to the State Department, July 21, 1947.

${ }^{18}$ Ibidem.

${ }^{19}$ Ibidem. W tym czasie komuniści greccy nie opowiadali się za tworzeniem „Wolnej Macedonii”, natomiast za włączeniem do walki ludności słowiańskiej.

${ }^{20}$ NA, FO 371/66985 HP 0021 R.10224/1296/67, Outward Saving Telegram from Commonwealth Office, Macedonia, 26th July 1947.

${ }^{21}$ NA FO 371/66997, Foreign Office, S.W.I. 24 January 1947, United Kingdom Delegation from New York. Yugoslav-Bulgarian Federation. Ralph Clarmont Skrine Stevenson funkcję tę pełnił od 17 sierpnia 1943 r. do 13 sierpnia 1946 r., jego następcą został Charles Peake.

${ }^{22}$ Ibidem. 
kowo-Wschodniej i na Bałkanach zmieniły się priorytety polityki sowieckiej. Już 6 marca 1946 r. Churchill nawoływał mocarstwa anglosaskie do ścisłej współpracy, mówiąc o ,żelaznej kurtynie”. Przedstawiona 12 marca 1947 r. przez prezydenta Harry’ego S. Trumana $\mathrm{w}$ orędziu do Kongresu doktryna powstrzymywania, mająca zahamować ekspansję komunizmu, i zaprezentowany przez ówczesnego sekretarza stanu USA, George'a Marshalla 5 czerwca 1947 r. na Uniwersytecie Harvarda w Cambridge Mass. plan (tzw. plan Marshalla), którego celem była odbudowa gospodarek państw europejskich, stanowiły przedsięwzięcia, które, zmuszając Stalina do podjęcia zdecydowanych działań, wyznaczały nowe założenia sowieckiej polityki wobec Bałkanów.

W nowych warunkach na międzynarodowej scenie politycznej Stalin dążył do ugruntowania i spotęgowania swych wpływów w Europie Środkowo-Wschodniej i na Bałkanach, łącznie z własną strefą wpływów w Niemczech oraz w Jugosławii i Albanii, zwłaszcza że W ramach polityki powstrzymywania USA przejęły zobowiązania Wielkiej Brytanii wobec Grecji i Turcji. Po decyzji Wielkiej Brytanii z 24 lutego 1947 r. ${ }^{23}$ o wycofaniu swych wojsk z Grecji, były one stopniowo zastępowane przez żołnierzy USA. Jeśli idzie o wspomniane orędzie Trumana z 12 marca 1947, to odniósł się on bezpośrednio do sytuacji w Grecji i Turcji, podkreślając wolę udzielenia wsparcia tym, którzy stawią opór totalitaryzmowi i naciskom z zewnątrz. W ten sposób politykę powstrzymywania mocarstwa anglosaskie zaczęły realizować na tych obszarach, które miały dla nich żywotne interesy - w tym wypadku w Grecji i Turcji. W dniu 22 czerwca prezydent Truman podjął decyzję o przekazaniu 250 milionów dolarów na pomoc wojskową i ekonomiczną dla Grecji i 150 milionów dolarów dla Turcji.

\section{II}

Dla zacieśnienia kontaktów i rozwoju współpracy między Belgradem a Sofią doniosłe znaczenie miała oficjalna wizyta Dymitrowa w Jugosławii latem 1947 r. Dymitrowowi towarzyszyli najważniejsi ranga przedstawiciele rządu: minister spraw zagranicznych Kimon Georgiew, Anton Jugow - minister spraw wewnętrznych, Iwan Stefanow - minister finansów i handlu oraz Georgi Trajkow - zajmujący stanowisko ministra rolnictwa, przewodniczącego Naczelnej Rady Ekonomicznej oraz Dyrektora Generalnego Milicji. Jak raportowano z Ambasady Wielkiej Brytanii w Belgradzie 16 sierpnia 1947 r., wizytę można było podzielić na dwie części. Pierwszą była manifestacja jugosłowiańskiej sympatii dla Związku Sowieckiego i jego przywódcy - Stalina oraz Tity, ale także dla Bułgarii i narodu bułgarskiego. Wzdłuż kolejnych tras przejazdu delegacji budynki dekorowano flagami obu krajów oraz portretami Stalina, Tity i Dymitrowa, a ludność wznosiła okrzyki przyjaźni „Stalin - Tito - Dymitrow, Moskwa - Belgrad - Sofia ${ }^{24}$ ”.

Drugą część stanowiły obrady w Bled dnia 30 lipca i 1 sierpnia, które wieńczyło podpisanie porozumień, i chociaż jednym z zasadniczych tematów toczonych wówczas politycznych dyskusji była kwestia macedońska, w końcowym protokole nie zamieszczono

\footnotetext{
${ }^{23}$ Amerykanie otrzymali z Londynu notę, w której informowano, że najpóźniej do 1 kwietnia wycofają 40 tys. swych żołnierzy.

${ }^{24}$ Istoriczeskite reszenija w Bled, „Politiczeski dwiżenija”, nr 9, Sofija 1947 g., s. 11-18.
} 
o tym żadnej wzmianki. Charles Peake, ambasador brytyjski w Jugosławii, we wspomnianym raporcie z 16 sierpnia 1947 r. cytował wypowiedzi Tity i Dymitrowa na ten temat. Tito publicznie twierdził, że nie prowadzono rozmów na temat Grecji, a jeśli ją wspomniano, to wyłącznie w kontekście czysto obronnym. Natomiast Dymitrow zaprzeczył, by rozważano utworzenie jakiejś południowosłowiańskiej lub bałkańskiej federacji. Peake podsumowat:

Stworzenie jakiejkolwiek formy federacji południowosłowiańskiej jest na pewno kwestią, która musi być decydowana przez Sowietów, nie przez bułgarski czy jugosłowiański rząd. Nie wierzę, iż decyzja może być podjęta i zakończona sukcesem w jakiś sposób wyłącznie na bułgarsko-jugosłowiańskiej konferencji ${ }^{25}$.

Peacke stał na stanowisku, że sprawy dotyczące Grecji i Dunaju, o których była mowa po konferencji, zapewne w praktyce zostały ustanowione wcześniej.

Późniejsze wydarzenia wskazuja, że Peake miał rację. Jednak zapewnienia Tity i Dymitrowa o braku rozmów o przyszłej federacji i kwestii macedońskiej nie były prawdziwe; bowiem toczyły się one niejawnie i dotyczyły planowanej federacji bułgarsko-jugosłowiańskiej $^{26}$.

W Bled Tito i Dymitrow podpisali całkowicie tajną umowę o włączeniu Piryńskiej Macedonii (bułgarskiej) do Ludowej Republiki Macedonii, istniejącej w ramach federacji jugosłowiańskiej. Tym samym bardzo trudno jest stwierdzić, czy w Bled obaj komunistyczni przywódcy planowali szerszą federację, z grecką częścią Macedonii, w której toczyły się zacięte walki komunistów greckich. Wiadomo natomiast, że starcia zbrojne - za przyzwoleniem Stalina - były intensywnie wspierane tak przez Belgrad, jak i Sofię. Nadto trzeba podkreślić, że przy podpisywaniu umowy był obecny premier Ludowej Republiki Macedonii, Lazar Koliševski.

Ponieważ umowa trzymana była w ścisłej tajemnicy, a w jej zapisach stwierdzono, że o zjednoczeniu decydować będą dwa państwa: Bułgaria i Jugosławia, nie wspominając o roli Sowietów w tym projekcie, najczęściej przyjmuje się tezę, że o podpisanej w Bled umowie dotyczącej federacji bułgarsko-jugosłowiańskiej Stalin nie wiedział ${ }^{27}$. Analizując sytuację w 1947 r., nie jest to oczywiste, a wręcz nieprawdopodobne ${ }^{28}$. Stalinowi, ze względu na nową sytuację polityczną (zwłaszcza że w Grecji znaleźli się Amerykanie), zależało na wyciszeniu na arenie międzynarodowej problemu planowanej federacji, której podstawowym celem miała być ściślejsza kontrola Jugosławii przez Sowietów za pośrednictwem Bułgarii, na terenie której wpływy Moskwy były ugruntowane. Mimo że Stalin zainteresowany był utworzeniem takiej federacji, weto brytyjskie i amerykańskie do czasu podpi-

\footnotetext{
${ }^{25}$ NA, FO 371/66958, No. 216/11/47, Embassy of Great Britain in Belgrade, August 16, 1947.

${ }^{26}$ Arhiv na Makedonija (dalej AM), f. 1100 MNR na FNRJ kutja 3, Elaborat političko-ekonomsko stanje u Bugarskoj. Radjen maja 1950 godine, s. 49.

${ }^{27}$ Por. E. Znamierowska-Rakk w pracy Federacja Stowian..., s. 325- 335, oraz P. Żurek, Stowenia pod rzqdami Tity (1945-1980). W cieniu Jugosławii, Kraków 2017, s. 82, a także M. Łałkow, Ot nadeżda kym razoczarowanie. Idejata na federacijata w Bałkanski jugoiztok (1944-1948), Sofija 1994, s. 251-255.

${ }^{28}$ Zob. M. Djilas, Rozmowy ze Stalinem..., s. 151, 152. W czasie pobytu na Kremlu 10 lutego 1948 r. Kardelj wskazywał, że w Bled stopniowo pracowano nad utworzeniem takiej federacji, na co Stalin miał powiedzieć, że federacja ma powstać natychmiast. Najpierw powinny się połączyć Jugosławia i Bułgaria, a potem z nimi Albania.
} 
sania traktatu pokojowego w Paryżu 10 lutego 1947 r. uniemożliwiało mu takie działania. Jednak pod koniec lipca i na początku sierpnia Bułgaria znalazła się w nowej sytuacji politycznej.

Z podpisanej umowy wynika, że o czasie i warunkach zjednoczenia dwóch części Macedonii decydować będzie nie tylko Belgrad, ale także Sofia. Pod datą 1 sierpnia 1947 r. Dymitrow zanotował w swym Dzienniku: „Uzgodniliśmy z Tito i przedstawicielem macedońskiej władzy ogólną linię w sprawie macedońskiej. Nie będzie bezpośredniego włączenia Piryńskiego Kraju do macedońskiej Republiki" ${ }^{29}$. Był to główny cel tego układu, na którym bardzo zależało zarówno Dymitrowowi, jak i Stalinowi.

Cała umowa Dymitrow-Tito składała się z czterech punktów. W punkcie 1. obie strony zgodziły się, że do rozstrzygania o ostatecznym zjednoczeniu dwóch części Macedonii (bułgarskiej i jugosłowiańskiej) będą w pełni uprawnione oba państwa - Jugosławia i Bułgaria. Nie jest dopuszczalne, by Ludowa Republika Macedonii w jakikolwiek sposób mieszała się w wewnętrzne sprawy w Macedonii Piryńskiej, a wszelkie kontakty między nimi uzgadniane będą przez władze Jugosławii i Bułgarii.

Punkt 2. stanowił o podjęciu szerokich działań mających na celu popularyzację Bułgarii i Macedońskiego Kraju w Jugosławii oraz LRM i Jugosławii w Bułgarii, co zamierzano realizować przez działania kulturalne: tworzenie instytucji do tego powołanych, tj. teatrów, macedońskich księgarń, szkół, nauczanie macedońskiej literatury, języka, historii w szkołach na terenie Macedońskiego Kraju, co z kolei zostało zapisane w punkcie 3.

Bardzo ważny był zapis w punkcie 4., który stanowił, że podstawą zjednoczenia będzie podpisany w przyszłości sojusz między Jugosławią i Bułgarią, natomiast w obecnej chwili nie będzie się stawiało zagadnienia zjednoczenia, ani nie będzie się prowadziło działań propagandowych $\mathrm{w}$ tym kierunku ${ }^{30}$.

W znajdującym się w archiwum w Skopiu raporcie, pochodzącym z 1950 r. i dotyczącym polityczno-ekonomicznej sytuacji w Bułgarii, można przeczytać:

1. „W Bled podpisano umowę o włączeniu Piryńskiej Macedonii [do Ludowej Republiki Macedonii - I. S.-K.], co osiągnięte będzie przez akt utworzenia federacji przez Bułgarię i Jugosławię?". Pytajnik w tym zdaniu tłumaczy, że nie było wiadomo, czy miała być to tylko federacja bułgarsko-jugosłowiańska, czy szersza. Piszący raport nie uściślili tych informacji.

2. „Drugą decyzją ... podpisanej w Bled umowy było ostateczne zjednoczenie, które miało nastąpić przez decyzje Bułgarii i Jugosławii.... Nie każdy przestrzega zdrowego rozsądku, by nie było ingerencji z zewnątrz". Komentarz ten świadczy, iż w umowie nie wspomniano o roli, jaką w tym zjednoczeniu odegrałby Związek Sowiecki.

3. „Praca kulturalna [w Piryńskiej Macedonii - I. S.-K.] powinna być prowadzona pod kierunkiem bułgarskich władz, co może powodować zagrożenia, a nawet szkody"31.

${ }^{29}$ G. Dimitrow, Dniewnik (9 mart 1933-6 fewruari 1949), red. D. Sirkow, P. Boew, N. Awrejski, E. Kabakcziewa, Sofija 1997, s. 554.

${ }^{30} \mathrm{CPA}$, f. 146 , op. 5, a.e. 490 , Położenija, premi ot jugoslavskija i byłgarskija ministyr predsedatel po wyprosa za makedonskija kraj w Byłgarija, podpisan ot G. Dimitrow, Bled 1. awg. 1947. Por. E. Znamierowska-Rakk, Federacja..., s. 329 i nast.

${ }^{31}$ AM, f. 1100 MNR na FNRJ, kutja 3, Elaborat političko-ekonomsko stanje u Bugarskoj. Radjen maja 1950 godine, s. 49. 
Chodziło o mieszkańców bułgarskiej części Macedonii, poddawanych propagandzie promacedońskiej, a nawet represjonowanych, gdy uznawali, że ich tożsamość narodowa nie jest macedońska, lecz bułgarska ${ }^{32}$.

W porównaniu z założeniami politycznymi przyjętymi w 1946 r. umowa dawała Dymitrowowi - wówczas gdy Tito wyrósł na czołowego przywódcę komunistycznego na Bałkanach - gwarancje przyjaźni i partnerstwa obu bałkańskich liderów oraz zapewnienie, że o wspomnianym zjednoczeniu będzie decydował na równi z Titą. Jest rzeczą oczywistą, że nie tylko Dymitrowowi, ale też Stalinowi zależało, aby akt zjednoczenia oraz życie kulturalno-naukowe w Piryńskiej Macedonii były kontrolowane przez towarzyszy bułgarskich.

Jak donosił 12 sierpnia 1947 r. urzędnik Biura Brytyjskiego Politycznego Przedstawicielstwa (Office of the British Political Representative) w Sofii ministrowi spraw zagranicznych Wielkiej Brytanii Ernestowi Bevinowi, Dymitrow, podczas pobytu w Jugosławii, w wywiadach dla zagranicznej prasy wypowiadał się negatywnie o możliwości powstania federacji bałkańskiej. Takiej samej wypowiedzi udzielił dla prasy greckiej (dla „Rizospastis") jeszcze przed wizytą w Bled. Stąd przekonanie, że koncepcja federacji południowych Słowian została zamrożona ${ }^{33}$. W 1947 r. Stalin osiągnął swój cel, a sprawa federacji południowych Słowian przez przywódcę sowieckiego została wyciszona.

Amerykański ambasador w Jugosławii, Cavendish W. Cannon, raportował z Belgradu, że reżim Tity cieszy się znaczną wolnością, Sowieci bowiem nie ingerują w prowadzoną przez niego politykę wewnętrzną i tempo realizowania programów komunistycznych. Jeśli zaś chodzi o politykę zagraniczna, Cannon oceniał, że Jugosławia wyróżnia się jako najwierniejszy i najbardziej sumienny współpracownik Sowietów, a nie jako ich satelita. Jednocześnie określił Titę jako dynamicznego przywódcę, zwolennika ekspansji komunizmu. Wówczas, ze względu na zaostrzający się podział Wschód-Zachód, nie przewidywał w najbliższej przyszłości konfliktu między Stalinem a Titą ${ }^{34}$.

\section{III}

J.C. Sterndale Bennett w swym raporcie o spotkaniu w Bled, wysłanym z Sofii 20 sierpnia 1947 r., przytoczył wypowiedzi bułgarskiego ministra spraw zagranicznych dotyczące samych rozmów i dokumentów podanych do publicznej wiadomości po ich zakończeniu ${ }^{35}$. Protokół z Bled dotyczył bowiem wielu ważnych spraw i znalazł omówienie w opublikowanym komunikacie. Według rozmówcy obie strony zaniepokojone były faktem opublikowania projektu Traktatu o przyjaźni, współpracy $i$ wzajemnej pomocy ${ }^{36}$, który dołączony był do innych umów i dokumentów podpisanych w Bled. W literaturze Traktat ten znany

\footnotetext{
${ }^{32}$ Ibidem.

${ }^{33}$ NA, FO 371/66958, Office of the British Political Representative Sofia, 12th August 1947, to Ernest Bevin.

${ }^{34}$ FRUS, 1947, vol. IV, The Ambassador in Yugoslavia (Cannon) to the Secretary of State, Belgrade, September 7, 1947, s. 842 .

${ }^{35}$ NA, FO 371/66958, Bulgaro/Yugoslav Conversation at Bled, J.C. Sterndale Bennett, 20th August 1947.

${ }^{36}$ NA, FO 371/66958, No. 216/11/47, British Embassy, Belgrade, 16th August 1947.
} 
jest także jako bułgarsko-jugosłowiański układ sojuszniczy ${ }^{37}$. Jak donosił 16 sierpnia 1947 r. z Belgradu ambasador brytyjski w Jugosławii Charles Peake - marszałek Tito zaznaczył jasno, że Traktat uzgodniony w Bled nie uzyskał dotąd formalnej akceptacji, gdyż obie strony czekają na wprowadzenie w życie traktatu pokojowego z Bułgarią, podpisanego 10 lutego 1947 r. w Paryżu ${ }^{38}$.

Protokół dotyczący rozmów w Bled składał się z czterech załączników:

1. Uzgodnionego tekstu Traktatu o przyjaźni, wspótpracy $i$ wzajemnej pomocy między Ludowa Republikq Bułgarii a Federacyjna Ludowa Republikq Jugosławii;

2. Umowy o wspólpracy gospodarczej między Ludowq Republikq Butgarii a Federacyjnq Ludowa Republikq Jugosławi;

3. Porozumienia $w$ sprawie ułatwień celnych i przygotowania unii celnej między Ludowa Republika Butgarii a Federacyjna Ludowa Republikq Jugosławii;

4. Porozumienia w sprawie dwupaństwowej własności na granicy bułgarsko-jugostowiańskiej w celu ułatwienia ludności jej przekraczania, zawartego między Ludowa Republika Bułgarii a Federacyjnq Ludowa Republikq Jugostawii ${ }^{39}$.

W protokole z konferencji w Bled znalazły się najważniejsze umowy i decyzje podjęte w Bled, do których zaliczono:

- utworzenie i uzgodnienie tekstu Traktatu o przyjaźni, wspótpracy i wzajemnej pomocy (potocznie zwanego układem sojuszniczym),

- postanowienia odnośnie do rozwinięcia współpracy handlowej i gospodarczej, w tym przygotowania unii celnej między Bułgarią i Jugosławią oraz uzgadniania planów biznesowych; współpraca gospodarcza dotyczyć miała koordynacji i harmonizacji płatności przez ustalenie kursu wymiany walut, a także wzajemnej pomocy w przemyśle, elektryfikacji, górnictwie, rolnictwie, transporcie i handlu zagranicznym,

- stworzenie poprzez zawarcie specjalnego porozumienia nowego systemu własności dwupaństwowej wzdłuż całej granicy bułgarsko-jugosłowiańskiej oraz zniesienie wiz dla obywateli obu krajów,

- rozbudowę połączeń kolejowych i drogowych między Bułgarią i Jugosławia,

- w związku z żądaniem Grecji z 3 grudnia 1946 r., skierowanym do Rady Bezpieczeństwa ONZ, by rozpatrzyć jej oskarżenia przeciwko Albanii, Bułgarii i Jugosławii o ingerencję w jej sprawy wewnętrzne, i powołaniem Komisji Ankietowej (Śledczej) w celu zbadania zasadności greckich skarg - wniosek o powołanie przez Zgromadzenie Ogólne Stałej Komisji Bałkańskiej, która by rozstrzygała spory rządu greckiego z trzema państwami bałkańskimi: Albanią, Bułgarią i Jugosławią,

- rozszerzenie współpracy kulturalnej między Bułgarią i Jugosławią, w celu wymiany dzieł literackich, czasopism, gazet i rozwijania wszelkich inicjatyw w tej dziedzinie,

${ }^{37}$ Dokładniej na temat jego podpisania, treści i znaczenia w polityce Stalina w dalszej części artykułu.

${ }^{38}$ NA, FO 371/66958, Bulgaro/Yugoslav Conversation at Bled... Traktat z Bułgarią wszedł w życie 15 września 1947 r., po jego ratyfikacji.

${ }^{39}$ Istoriczeskite reszenija $w$ Bled..., s. 51. 
- ułatwienie współpracy gospodarczej, koordynację planów gospodarczych, czemu sprzyjać miało zrzeczenie się przez Jugosławię reparacji wojennych ${ }^{40}$.

Stalin krytycznie odniósł się do Dymitrowa w obliczu ujawnienia treści Traktatu o przyjaźni, wspótpracy i wzajemnej pomocy między Ludowq Republika Butgarii a Federacyjnq Ludowq Republikq Jugostawii. Wezwany do Moskwy, 8 sierpnia spotkał się ze Stalinem i, jak podaje w swoim Dzienniku, ich rozmowy dotyczyły dwóch ważnych kwestii. Pierwszą było zbyt wczesne upublicznienie treści Traktatu z Jugosławią, tj. przed ratyfikacją traktatu pokojowego z Bułgarią ${ }^{41}$. Stalin dowodził, że Amerykanie i Anglicy mogą wykorzystać ten fakt, by zwiększyć pomoc wojskową dla Grecji i Turcjii' ${ }^{42}$.

Druga odnosiła się do czarnomorskiej granicy; chodziło bowiem o stworzenie nad Morzem Czarnym w Bułgarii wojskowo-morskiej bazy, ściśle połączonej z portem w Odessie, i przysłanie stamtąd floty wojennej, marynarzy i sprzętu wojskowego dla bułgarskiej armii, a szczególnie dla wojsk pogranicza ${ }^{43}$. Niemniej pomoc wojskowa Związku Sowieckiego dla Bułgarii miała być okryta ścisłą tajemnica, bo jak tłumaczył Stalin, w czasie wojny Bułgaria stała po stronie Hitlera ${ }^{44}$. Oczywiście chodziło o wzmocnienie sowieckiej pozycji nie tylko politycznej, ale i militarnej w Bułgarii po zakończeniu działalności przez Sojuszniczą Komisję Kontroli. Jak dużą wagę Stalin przywiązywał do podporządkowania sobie Bułgarii, wskazuje także pismo z dnia 12 sierpnia, wysłane z Kremla do Dymitrowa, w którym ostrzegał, że wojskowy sojusz (chodziło o punkt 3. Traktatu o przyjaźni, wspótpracy $i$ wzajemnej pomocy) może stworzyć niepotrzebną okazję do wzmocnienia anglo-amerykańskiej interwencji zbrojnej w Grecji i Turcji, która skierowana będzie przeciwko Jugosławii i Bułgarii. Jak dalej dowodził, nie może odpowiadać za umowy (pakty) o dużym znaczeniu, gdy chodzi o politykę zagraniczną jeśli zostaną zawarte bez konsultacji z sowieckimi władzami ${ }^{45}$. Było to równoznaczne $\mathrm{z}$ domaganiem się, by całkowicie podporządkować politykę zagraniczną Moskwie.

Podpisanie w Bled unii celnej między Jugosławią a Bułgarią i umowy o współpracy gospodarczej między tymi państwami Peake uznał za zaskakujące. Jednak niepłacenie reparacji wojennych przez Bułgarię na rzecz Jugosławii już wcześniej brane było pod uwagę. Jugosłowiański minister spraw zagranicznych twierdził: „...my też mamy swój własny plan Marshalla"46. Peake tak komentował założenia, których realizacji miało służyć spotkanie Tity z Dymitrowem:

Głównym celem wizyty [Dymitrowa w Bled - I. S.-K.] było, jestem tego prawie pewien, nie osiaggnięcie konkretnych rezultatów, ale zademonstrowanie solidarności oraz zamanifestowanie gwałtownego sprzeciwu w stosunku do rosnących interesów Stanów Zjednoczonych w Grecji i wobec planu Marshalla. Ton jugosłowiańskiej prasy i przemówień obu stron - bułgarskiej i jugosłowiańskiej - mocno utwierdziły mnie w tym zdaniu ${ }^{47}$.

${ }^{40}$ Ibidem, s. 49-51. NA, FO, 371/66958, Communique on Agreement between Delegations of Yugoslav and Bulgarian Governments. Całość tych decyzji podano w Komunikacie o porozumieniu między delegacją rządów Jugosławii i Bułgarii i przedrukowano w Belgradzie w gazecie „Tanjug”.

${ }^{41}$ Zob. obszerniej: A. Kastory, Jugosławia w polityce Stanów Zjednoczonych, Wielkiej Brytanii i Zwiqzku Sowieckiego 1948-1956, Kraków 2018, s. 15.

${ }^{42}$ G. Dimitrow, Dnewnik..., s. 555. Zob. także E. Znamierowska-Rakk, Federacja ..., s. 332 i nast.

${ }^{43}$ Ibidem.

${ }^{44}$ Ibidem.

${ }^{45}$ Ibidem, s. 556.

${ }^{46}$ NA, FO 371/66958, No. 216/11/47 British Embassy, Belgrade, 16th August, 1947.

${ }^{47}$ Ibidem. 
W podobnym tonie o rozmowach w Bled wypowiadał się amerykański ambasador w Jugosławii, Cavendish W. Cannon:

Ambasada uważa, że głównym celem zwołania w tym szczególnym czasie konferencji w Bled nie było stworzenie podwalin pod federację bałkańską, ale raczej promowanie wojny nerwów odnośnie do Grecji i próba przekonania ... w myśl hasła: jedność, braterstwo i współpraca gospodarcza Słowian, społeczeństwa w tej części świata, że kraje pod ochronnym skrzydłem Związku Sowieckiego mają coś lepszego do zaoferowania, co będzie dla nich bardziej korzystne niż plan Marshalla ${ }^{48}$.

Z tego powodu w Londynie dokładnie analizowano warunki ekonomiczne bułgarskojugosłowiańskiego porozumienia zawartego w Bled. W raporcie o ekonomicznym znaczeniu umowy zwracano uwagę na potencjał gospodarczy tak Jugosławii, jak i Bułgarii, podkreślając, że w obu państwach główną dziedziną gospodarki jest rolnictwo. Wymiana handlowa między tymi państwami stanowiła mniej niż 1\% bułgarskiego obrotu zagranicznego. Skoro produkty obu krajów są podobne, nie ma zbyt wielu powodów do utrzymania wymiany handlowej" ${ }^{49}$. Przyjmując dłuższą perspektywę, odnośnie do unii celnej, o której mówiła umowa z Bled, w raporcie stwierdzono:

... może być pierwszym krokiem w stworzeniu Bloku Wschodnioeuropejskiego bez barier taryfowych, co może wytworzyć konkretną siłę. Taka unia celna będzie wymagała powstania sprawnych linii komunikacyjnych, a także - udostępnienia polskiego węgla oraz rumuńskiej ropy krajom członkowskim dla polepszenia ich industrializacji. Skoro cały region jest biedny, zacofany i w większości rolniczy, nie można się spodziewać żadnych gwałtownych postępów ${ }^{50}$.

W raporcie zwracano też uwagę na fakt, że Jugosławia, która korzystała z pomocy UNRRA (United Nations Relief and Rehabilitation Administration - Administracja Narodów Zjednoczonych do spraw Pomocy $i$ Odbudowy), posiada zasoby górnicze, które moga być cennym wsparciem dla bułgarskiego rządu. Dla Bułgarii najważniejszym elementem porozumienia było zrzeczenie się reparacji, przez co wiele zyskała. Jugosławia natomiast zdobyła moralne przywództwo. W podsumowaniu stwierdzono, że ekonomiczne warunki tego porozumienia są podyktowane koniecznością zamanifestowania słowiańskiej jedności i pojednania ${ }^{51}$.

\section{IV}

W pełni widoczne były założenia prowadzonej przez Stalina polityki, któremu chodziło o to, by odrzucając plan Marshalla, dać wyraz jedności państw Europy Środkowo-Wschodniej i Bałkanów i pokazać, że kraje pozostające w obrębie wpływów Moskwy moga przez podpisanie wzajemnych umów o współpracy ekonomicznej stworzyć nieza-

${ }^{48}$ FRUS 1947, Eastern Europe; The Soviet Union, vol. IV, Sofia, November 7, 1947. W telegramie Hornera cytowana była depesza Cannona z 7 września 1947 r., Washington 1972, s. 849.

${ }^{49}$ NA, FO 371/66958, Economic clauses of the Bulgaro-Yugoslav agreement at Bled (July 31, 1947), Sofia, 2 September 1947.

${ }^{50}$ Ibidem.

${ }^{51}$ Ibidem. 
wodną alternatywę dla planu. Decydując się tym samym na rezygnację z pomocy oferowanej przez USA, Stalin kontrolowałby region nie tylko pod względem politycznym, ale i ekonomicznym ${ }^{52}$. Niemniej ponieważ jedynie Jugosławia i Związek Sowiecki były wówczas państwami zdecydowanie przeciwnymi planowi Marshalla ${ }^{53}$, za ważne zadanie uznał Stalin przyspieszenie procesu komunizacji w Europie Środkowo-Wschodniej i na Bałkanach $^{54}$. Krajem, w którym partia komunistyczna od 1945 r. rządziła samodzielnie, była Jugosławia. Tak szybkie tempo przejęcia władzy bez pomocy Stalina ${ }^{55}$ powodowało, że Tito cieszył się ogromnym autorytetem wśród komunistów bałkańskich. Również w Albanii pozostającej pod wpływem Belgradu komuniści - wówczas jeszcze za zgodą Kremla, który miał we władzach oddanego - Koçi Dzodze (alb. Koçi Xoxe) - przystąpili do rządów niezwłocznie z wykorzystaniem krwawych metod. Natomiast dla pozostałych państw Europy Środkowo-Wschodniej i Bałkanów rok 1947 stał się ważną cezurą. Na Węgrzech fałszywe oskarżenia przeciwko premierowi Ferencowi Nagyowi z Niezależnej Partii Drobnych Rolników spowodowały zdecydowane przejęcie władzy przez Komunistyczną Partię Węgier. W Rumunii w listopadzie internowano króla Michała I, by 30 grudnia zmusić go do abdykacji, co oznaczało ostateczną klęskę przeciwników komunizmu. W Bułgarii w celu uchwalenia konstytucji - w 1947 r. przeprowadzono parlamentarne wybory, w których kandydaci Frontu Ojczyźnianego zdobyli 70\% mandatów, a premierem został Dymitrow. Natomiast w Czechosłowacji dopiero 25 lutego 1948 r. w wyniku przewrotu komuniści pozbawili opozycję realnej władzy ${ }^{56}$.

Stalin uznał, że najlepszym narzędziem do zrealizowania jego planu całkowitego podporządkowania regionu będzie powołanie Biura Informacyjnego Partii Komunistycznych (Kominformu), które miało koordynować wszystkie działania partii komunistycznych ${ }^{57}$. Pozornie takie założenie było zgodne z polityką zarówno Belgradu, jak i Sofii, wzywających do utworzenia instytucji, która nawiązywałaby do koncepcji Kominternu i idei „światowej rewolucji" ${ }^{58}$. Niemniej w 1947 r. inne były cele, które wytyczył Stalin - pragmatyczny polityk, starający się powściagnąć jugosłowiańskie nawoływania do rewolucji kierowane do komunistów włoskich i francuskich. Natomiast w Europie Środkowo-Wschodniej i na Bałkanach zwiększał tempo stalinizacji, podporządkowania i zdyscyplinowania.

52 J. Janus, Polska i Czechostowacja wobec Planu Marshalla, Kraków 2001, s. 154 i nast.

${ }^{53}$ Stalin obawiał się, że pomoc USA może zburzyć jedność Europy Środkowo-Wschodniej i Bałkanów.

${ }^{54} \mathrm{Na}$ temat zob. A. Kastory, Mocarstwa wobec kryzysów w europejskich krajach sowieckiej strefy wptywów 1948-1968, Kraków 2015.

${ }^{55}$ Oddziały Armii Czerwonej brały czynny, ale zarazem symboliczny udział w wyzwalaniu Belgradu.

${ }^{56}$ Dokładniej zob. A. Kastory, Mocarstwa wobec kryzysów...

${ }^{57}$ Takie plany Stalin snuł już w marcu 1946 r. Ich realizacja została jednak odroczona, aby uniknać potencjalnego negatywnego efektu podczas zbliżających się wyborów we Francji, Czechosłowacji i Rumunii, a także w trakcie negocjacji traktatu pokojowego. Zob. C. Békés, Soviet Plans to Establish the Cominform in Early 1946: New Evidence from the Hungarian Archives, [w:] Cold War International History Project, Bulletin 10, Washington 1998 , s. 135.

${ }^{58}$ W czerwcu 1946 r. Stalin zaproponował Ticie, by inicjatywa powołania Kominformu wyszła ze strony jugosłowiańskiej, na co ten wyraził zgodę. Tego samego dnia Stalin na rozmowę zaprosił oprócz Tity także Dymitrowa, podejmując dyskusję o tym, kto miał być inicjatorem przyszłej Międzynarodówki. Wówczas Stalin brał pod uwagę także stronę bułgarską, jak i komunistów francuskich. Na ten temat: V. Dedijer, Dokumenti 1948. ..., dok. 26, Infomaciono savetovanje nekih komunističkih partija. Kominike, Beograd, 5. Oktobar 1947, godine, s. 148. Por. M. J. Zacharias, Idee, utopie, rzeczywistość. Myśl polityczna Milovana Djilasa (1911-1995), Bydgoszcz 2015 , s. $78,79,81$. 
Do Szklarskiej Poręby w dniach 22-27 września 1947 r., gdzie zwołano założycielskie spotkanie Kominformu, ściągnięte zostały tylko niektóre partie komunistyczne. Jak donoszono z Belgradu, zaproszono delegacje z tych państw, które po drugiej wojnie światowej, znalazły się w strefie wpływów Sowietów, tj. z Jugosławii, Bułgarii, Rumunii, Węgier, Czechosłowacji i Polski. Ponadto goszczono przedstawicieli dwóch najprężniejszych partii komunistycznych w Europie: Francji i Włoch ${ }^{59}$. Nie zaproszono natomiast Albanii (w której przyspieszenie sowietyzacji nie było potrzebne) oraz Grecji, która ... „,nie przypadła strefie wpływów ZSRS, dlatego jasne jest, dlaczego Stalin nie powołał jej do prac nad powołaniem Kominformu" ${ }^{60}$. Nieobecność przywódców greckiej partii komunistycznej w Szklarskiej Porębie oznaczała, że Stalinowi nie chodziło w 1947 r. o poszerzanie swych wpływów, ale że rozpoczął tworzenie zwartego bloku państw w Europie Środkowo-Wschodniej i na Bałkanach, podporządkowanego Moskwie, takiego który byłby zdolny do przeciwstawienia się Zachodowi. Wykluczał on wówczas wszelką niezależność w polityce wewnętrznej i zagranicznej tak Tity, jak i Dymitrowa ${ }^{61}$.

Tymczasowy amerykański chargé d'affaires w Bułgarii, A. John Evarts Horner, twierdził, że prawdopodobnie jedynie federacja bułgarsko-jugosłowiańska w obecnej sytuacji jest radzieckim oficjalnym celem politycznym, przy czym trudno było określić, w jakim czasie miałoby dojść do jej utworzenia. Bałkany są obszarem wielu animozji, które można by uciszyć, ale liczy się także przywództwo polityczne - kto miałby odgrywać pierwszorzędną rolę wśród południowych Słowian - Tito czy Dymitrow. Horner twierdził, że na Bałkanach: „,nad marszem radzieckiej dominacji nad państwami satelickimi... wciąż utrzymuje się niepewność" 62 .

Stalin, wprowadzając nową strategię wobec państw Europy Środkowej i Bałkanów, już w 1947 r. musiał - po wejściu wojsk amerykańskich do Grecji - zrezygnować z planów federacyjnych z Grecją, ale ciagle utrzymywał tę decyzję w tajemnicy. Została ona ujawniona w lutym 1948 r., w czasie spotkania delegacji jugosłowiańskiej i bułgarskiej na Kremlu $^{63}$. Jednak pozwalał, by trzy kraje bałkańskie: Albania, Bułgaria i przede wszystkim Jugosławia, wciąż wspierały walczących w Grecji komunistów. W wyniku rozmów między przedstawicielami KPJ i KPG w październiku 1946 r. zawarto porozumienie o współpracy między partyjnymi i wojskowymi strukturami NOF (Narodowowyzwoleńczy Front - mac. Narodnoosloboditelen front) Macedończyków z Egejskiej Macedonii oraz strukturami NOF z LRM, w skład których wchodzili głównie komuniści uciekający przed represjami z Grecji. W dniu 21 listopada 1946 r. oddziały NOF włączone zostały do DAG. 10 sierpnia 1947 r. w akcie statutowym nr 5 Główny Sztab DAG przyznał Macedończykom szerokie

${ }^{59}$ V. Dedijer, Dokumenti 1948. ..., dok. 26, Infomaciono savetovanje nekih komunističkih partija. Kominike, Beograd, 5. Oktobar 1947, godine, s. 149. O roli, jaką w planach Stalina mieli odegrać komuniści włoscy i francuscy, zob. M. J. Zacharias, Powolanie Kominformu..., s. 110.

${ }^{60}$ V. Dedijer, Dokumenti 1948..., dok. nr 26, s. 148.

${ }^{61}$ A. Kastory, Jugosławia w polityce Stanów Zjednoczonych, Wielkiej Brytanii i Zwiazku Sowieckiego 1948-1956, s. 13; H. Bartoszewicz, Polityka Zwiqzku Sowieckiego wobec państw Europy Środkowo-Wschodniej w latach 1944-1948, Warszawa 1999, s. 322, 324. Inaczej przedstawiała się sytuacja w Albanii. W drugiej połowie 1947 r. Stalin zaczął umacniać swe gospodarcze wpływy w tym państwie. Wykluczył federację jugosłowiańsko-albańską bez uprzedniego utworzenia federacji bułgarsko-jugosłowiańskiej.

${ }^{62}$ FRUS 1947, Eastern Europe; The Soviet Union, vol. IV, Sofia, November 7, 1947, s. 849.

${ }^{63}$ Cold War International History Project, Bulletin 10, Washington 1998, red. L.Ia. Gibianskii, Dok. III, Report of Milovan Djilas about a secret Soviet-Bulgarian-Yugoslav meeting 10 February 1948, s. $130,133$. 
prawa kulturalno-oświatowe, w tym do nauczania w ojczystym języku dzieci w szkołach. W latach 1947-1949 w Egejskiej Macedonii otwarto 87 szkół, w których około 10 tys. uczniów pobierało naukę w języku macedońskim; Macedończycy prowadzili również ożywioną działalność w swoich towarzystwach kulturalno-oświatowych. Uzyskanie przez Macedończyków praw, które potwierdzały ich tożsamość i odrębność narodową, sprawiało, że w czasie greckiej wojny domowej w latach 1946-1949 masowo walczyli po stronie KPG. Według źródeł macedońskich spośród 35 tys. żołnierzy DAG 15 tys. stanowili Macedończycy, walczyli oni w zorganizowanych strukturach: NOF, AFŽ (mac. Antifašistički front na ženite - Antyfaszystowski Front Kobiet) i NOMS (mac. Narodnoosloboditelen mladinski sojuz - Narodowowyzwoleńczy Związek Młodzieży) ${ }^{64}$.

Natomiast w Bułgarii w celu przyłączenia Macedonii Piryńskiej do LRM prowadzono masową działalność propagandową i kulturalno-oświatową ${ }^{65}$. W pierwszym półroczu $1947 \mathrm{r}$. Bułgaria i Jugosławia podpisały szereg umów, z których wymienić należy m.in. konwencję o współpracy kulturalnej i oświatowej (z 9 maja 1947 r.). Do Macedonii Piryńskiej (bułgarskiej) udawali się macedońscy nauczyciele i działacze oświatowi. Powstało Jugosłowiańsko-Bułgarskie Towarzystwo Kulturalne, w Gornej Dżumai (obecnie Błagojewgrad) rozpoczął działalność Macedoński Teatr Narodowy, otwierano macedońskie księgarnie. Przystąpiono do drukowania gazet „Nova Makedonija”, „Mlad Borec”66. Symboliczne znaczenie miało przeniesienie do Skopia Macedońskiego Instytutu Naukowego, wydającego szereg książek oraz czasopism naukowych, które mówiły o bułgarskim charakterze Macedonii. W 1947 r. duża część tych zbiorów bibliotecznych i etnograficznych trafiła do Instytutu Historii Narodowej i Macedońskiej Akademii Nauki i Kultury w Skopiu, gdyż Dymitrow uznał, że właśnie tam rozwija się macedońska nauka, kultura i sztuka.

Działania te mogły dowodzić, że sprawa federacji nadal pozostawała aktualna, a wzmożenie prac nad „macedonizacją" ${ }^{67}$ Macedonii Piryńskiej utwierdzać mogło w przekonaniu, że idea federacji bułgarsko-jugosłowiańskiej zostanie urzeczywistniona w najbliższym czasie.

\section{V}

Oczekiwana wizyta Tity w Bułgarii uległa opóźnieniu, tak że zamiast 23 listopada 1947 r. - jak planowano - marszałek rozpoczął ją 25 listopada. Oficjalnie tłumaczono, iż powodem dwudniowego spóźnienia było złe samopoczucie (grypa) Tity ${ }^{68}$. W poufnym

${ }^{64}$ Dane zaczerpnięto z pracy: S. Kiselinovski, Egejskiot del na Makedonija (1913-1989), Skopje 1990, s. 137,138 .

${ }^{65}$ V. Dedijer, Dokumenti..., dok. 24, Jopsif Visarionovič Stalin - Edvard Kardelj, Moskva, mart 1947, godine, s. 140, 141. W rozmowie Kardelja ze Stalinem padło pytanie, w jakim języku mówią Macedończycy. Kardelj wyjaśnił, że ci mają swój język i literaturę, ...,ponieważ sprawiał wrażenie, że nie zna tych zagadnień, przypomniałem mu, że mieliśmy pewne nieporozumienia dotyczące Macedonii z bułgarskimi towarzyszami. W tej rozmowie Mołotow wspomniał, że Bułgarzy są zbyt ostrożni, aby poruszyć tę kwestię".

${ }^{66}$ Szerzej na ten temat: I. Stawowy-Kawka, Historia Macedonii, Warszawa-Wrocław-Kraków 2000, s. 264; E. Znamierowska-Rakk, Bułgarzy czy Macedończycy? Wokół spisu ludności w Macedonii Piryńskiej z grudnia 1946 r., Studia Środkowoeuropejskie i Bałkanistyczne, t. XXVI (2017), s. 245-261, Eadem, Federacja Stowian ..., s. 339-349.

${ }^{67}$ Termin „,macedonizacja” powstał w Bułgarii i oznacza szerzenie kultury, nauki i języka w Macedonii Piryńskiej (bułgarskiej), gdzie żyli Bułgarzy.

${ }^{68}$ NA, FO 371/66958, British Legation, Sofia, 4th December 1947. 
raporcie J.C. Sterndale Bennett donosił z Sofii, że po długiej nieobecności Dymitrowa w kraju chodziło o owiane tajemnicą ustalenia w Bled, na których realizację oczekiwali Tito i jego otoczenie ${ }^{69}$. Wcześniej Dymitrow przebywał w Moskwie, gdzie uzyskał zapewne instrukcje, jak ma przebiegać wizyta Tity w Bułgarii ${ }^{70}$.

W swojej relacji Bennett podkreślał, że wizyta była dobrze przygotowana pod względem propagandowym. Wzdłuż całej trasy podróży, na każdym przystanku, Titę witały entuzjastyczne tłumy. Jednak przemówienia obydwu przywódców nie odnosiły się bezpośrednio do tworzenia w przyszłości federacji bułgarsko-jugosłowiańskiej, a ich spotkanie było traktowane jako manifestacja „,braterstwa oraz jedności”71. Bennett zaznaczył, że w swych wystąpieniach Tito i Dymitrow akcentowali równość i autonomię obu państw. Wszakże na bułgarskiej stacji kolejowej przy granicy z Jugosławią (magistrala kolejowa Sofia-Niš) thum przywitał jugosłowiańskiego przywódcę okrzykami: „Nie chcemy granicy"72. Po podpisaniu 27 listopada w Ewksinogradzie koło Warny Traktatu o przyjaźni, wspótpracy i pomocy wzajemnej między Bułgarią i Jugosławią (potocznie nazywanego układem sojuszniczym) Tito, wykorzystując podobne slogany o przestrzeganiu woli narodów, by „stworzyć potężną słowiańską jedność”, głosił hasła: „nie chcemy granic”, „,hcemy federacji" 73 . Jednak oficjalnego oświadczenia nie wydano. W praktyce tak komentował tę sytuację Bennett: ,jeśli federacja jest zgodna z oczekiwaniami Kremla, wydaje się, iż nie ma wyraźnego wzrostu popularności i entuzjazmu dla połączenia [Bułgarii - I. S.-K.] z Jugosławią..." 74 .

Natomiast w raporcie z Belgradu donoszono, iż w delegacji Tity nie znalazł się członek jugosłowiańskiego Prezydium, Dimitar Vlahov ${ }^{75}$, „stary macedoński agitator”, nawołujący do zjednoczenia Macedonii składającej się z trzech części ${ }^{76}$. Znamienne, że osoba, która, jak sądzono, odgrywała ważną rolę w negocjacjach dotyczących kwestii macedońskiej, nie znalazła się u boku Tity w czasie podróży do Bułgarii. Zresztą wątek Macedonii w czasie oficjalnych wystąpień nie został poruszony, co mogło oznaczać, że rozwiązanie skomplikowanego problemu macedońskiego odłożono w czasie, a skupiono się na relacjach bułgarsko-jugosłowiańskich.

Dla Stalina najważniejsze było podpisanie Traktatu o przyjaźni, wspótpracy $i$ wzajemnej pomocy między Bułgarią i Jugosławią, co tworzyło system zabezpieczenia sowieckich wpływów w Europie Środkowo-Wschodniej i na Bałkanach oraz współpracy między państwami regionu. Podobne traktaty Jugosławia podpisała z następującymi państwami: z Albanią 10 lipca 1946 r., z Węgrami 8 grudnia 1947 r. i z Rumunią 19 grudnia 1947 r.

${ }^{69}$ Ibidem.

${ }^{70}$ Po powrocie z Moskwy 16 listopada 1947 r. Dymitrow spotkał się 17 listopada ze swymi najbliższymi współpracownikami, którzy rozmawiali o programie wizyty Tity w Bułgarii oraz o podpisaniu podobnego układu jak z Jugosławią także z Rumunią, Czechosłowacją, Polską, Albanią i Węgrami. Zob. G. Dymitrow, Dnevnik..., s. 589.

${ }^{71}$ NA, FO 371/66958, British Legation, Sofia, 4th December 1947.

${ }^{72}$ Ibidem.

${ }^{73}$ Ibidem.

${ }^{74}$ Ibidem.

${ }^{75}$ Dimitar Vlahov pochodził z Macedonii Egejskiej z Kilkis (mac. Kukuš).

${ }^{76}$ NA, FO 371/6698, British Embassy, Belgrade, Southern Department, Foreign Office, 10th December, 1947. 
Analizując treść Traktatu, często nazywanego układem sojuszniczym (ze względu na jego punkt 3. i 4.), należy zwrócić uwagę na preambułę, w której określono jego główne zadania:

Pewni, że braterskie zbliżenie i wąska współpraca odpowiada długofalowym aspiracjom narodów Federacyjnej Ludowej Republiki Jugosławii i bułgarskiemu narodowi, który w tym widzi silną gwarancję swej wolności i niezależności, swojego rozwoju i rozkwitu, a także bezpieczeństwa i utrwalenia pokoju na Bałkanach ...jednocześnie stanowi kamień węgielny dla zbudowania przyjaźni i współpracy wszystkich bałkańskich narodów... ${ }^{77}$

W jej dalszej części stwierdzono, że przynależność Bułgarii podczas drugiej wojny światowej do państw Osi nie wyklucza jej braterstwa i współpracy z Jugosławią, z poszanowaniem niezależności i jedności terytorialnej obydwu państw. Całość składała się z ośmiu artykułów. Pierwszy z nich stanowił, iż współpraca Bułgarii i Jugosławii odbywać się będzie z korzyścią dla nich obu, natomiast drugi odnosił się do zapewnienia przez obie strony bezpieczeństwa, niezależności i jedności w duchu zasad przyjętych przez ONZ, trzeci gwarantował wojskową pomoc w razie potrzeby, bez zwłoki i z wykorzystaniem dostępnych środków, gdyby jedno z państw podpisujących umowę zostało zaatakowane przez trzecie państwo. Nadto obie strony zagwarantowały, że nie będą zawierały żadnych innych przymierzy (sojuszy), które byłyby skierowane przeciwko drugiej stronie (punkt 4). Piąty dotyczył rozwoju współpracy ekonomicznej, szósty kulturalnej, natomiast siódmy popierania każdej inicjatywy, która prowadziłaby do usunięcia punktów zapalnych agresji W celu zabezpieczenia pokoju i bezpieczeństwa na świecie. W artykule ósmym znajdowały się ustalenia formalne, iż układ obowiązywał będzie 20 lat, a jego odnowienie nastąpić miało 12 miesięcy przed wygaśnięciem. Wchodził w życie zaraz po jego parafowaniu i ratyfikacji w Belgradzie. Jak było wspomniane, dokument podpisany w Ewksinogradzie 27 listopada 1947 r. przez Dymitrowa i Titę ${ }^{78}$ stanowił jedną z szeregu umów zawieranych przez państwa w Europie Środkowo-Wschodniej i na Bałkanach, tj. w sowieckiej strefie zależności. Natomiast sprawa federacji i priorytetów w polityce zagranicznej Stalina wypłynęła dopiero w 1948 r., powodując szereg zmian na bałkańskiej scenie politycznej i tym samym w relacjach bułgarsko-jugosłowiańskich ${ }^{79}$.

\section{Podsumowanie}

W 1947 r. polityka ZSRS wobec Zachodu i państw satelickich uległa zmianie ze względu na nowe wyzwania, którymi były: ogłoszona przez Trumana doktryna powstrzymywania oraz plan Marshalla. Stalin uznał, że osiągnięcie celów politycznych - w tym silniejsze podporządkowanie państw Europy Środkowo-Wschodniej i Bałkanów zapewni mu powołanie Biura Informacyjnego Partii Komunistycznych (Kominformu), które miało koordy-

${ }^{77}$ AM, f. 1100 - MNR i FNRJ kutja 2, Ugovor o prijateljstvu, saradnji i uzajamnoj pomoci izmedju Federativne Narodne Republike Jugoslavije i Narodne Republike Bugarske, s. 69-71.

${ }^{78}$ Ibidem.

${ }^{79} \mathrm{Na}$ temat postrzegania problemu federacji przez polityków jugosłowiańskich i bułgarskich oraz sowieckich obszerne opracowanie w 1949 r. przedstawił Moša Pijade, serbski polityk; znajduje się ono w Narodowym Archiwum w Londynie: NA, FO 371/78330, On the Question of a Balkan Federation by Moša Pijade, 1949. 
nować wszystkie działania partii komunistycznych. Na siedzibę Kominformu wybrano Belgrad $^{80}$. W samym 1947 r. punktem spornym między Moskwą a Belgradem i Sofią było podanie do publicznej wiadomości w Bled (1 sierpnia) treści Traktatu o przyjaźni, wspótpracy $i$ wzajemnej pomocy między Ludowa Republika Bułgarii a Federacyjna Ludowa Republikq Jugosławii. Zdaniem Stalina nastąpiło to zbyt wcześnie, w dodatku bez ustalenia z nim terminu. Oficjalnie Traktat został podpisany 27 listopada $1947 \mathrm{r}^{81}$

Tito i inni przywódcy jugosłowiańscy nigdy nie kwestionowali przyjaźni i przywódczej roli ZSRS, a Edvard Kardelj, bliski współpracownik Tity, w czasie spotkania na Kremlu 10 lutego 1948 r. z wcześniejszego ujawnieniu treści Traktatu tłumaczył się brakiem specjalnych wytycznych na ten temat ze strony Moskwy. Podobnie Dymitrow wyjaśniał, że dokument, który opublikowano w Bled (chodzi o Traktat), był wyłącznie oświadczeniem, a do publicznej wiadomości podano jedynie fakt jego uzgodnienia przez obie strony. Ani Stalin, ani Mołotow takich wyjaśnień nie chcieli słuchać, wypaczając stan faktyczny i ogłaszając, że o Traktacie dowiedzieli się z prasy. Kardelj (w imieniu Tity) i Dymitrow zostali upokorzeni i zmuszeni do przyznania się, że popełnili „błąd”. W 1948 r. nieporozumienie to stało się jednym z pretekstów do wypominania zarówno Ticie, jak i Dymitrowowi nieposłuszeństwa w sprawach polityki zagranicznej ${ }^{82}$. Inną sprawą była kwestia, jak dalece słowa Stalina, że działania obu przywódców mogły doprowadzić do niekorzystnych dla Jugosławii i Bułgarii, a tym samym dla Związku Sowieckiego, reakcji Zachodu, były prawdziwe i rzeczywiste, dzisiaj trudno ocenić ${ }^{83}$. Tego argumentu Stalin używał także na początku 1948 r., wymuszając posłuszeństwo na państwach bałkańskich.

Dało to podstawę do podpisania dnia 12 lutego 1948 r. w Moskwie oficjalnej umowy o konsultacjach w sprawach międzynarodowych (Umowa pomiędzy władzą ZSRS i FNRJ w sprawie konsultacji w kwestiach polityki zagranicznej - Ugovor izmedju vlade SSSR i vlade FNRJ o konsultaciji u spolnopolitičkim pitanjima). Kardelj, który był wezwany na Kreml o godz. 2.30 w nocy, by podpisać tę umowę w imieniu rządu jugosłowiańskiego,

\footnotetext{
${ }^{80}$ Świadczyć to może o dobrej współpracy sowiecko-jugosłowiańskiej. Zob. A. Kastory, Mocarstwa wobec kryzysów..., s. 48.

${ }^{81}$ W zaszyfrowanej notatce z rozmów z 10 lutego 1948 r. na Kremlu, Wasil Kołarow podaje - jako argument Stalina i Mołotowa za krytyką przywódców jugosłowiańskiego i bułgarskiego, brak określonego terminu funkcjonowania Traktatu oraz że miał wejść w życie natychmiast po jego podpisaniu. Zob. Dok. 185, s. 262-270, [w:] Makedonskijat wypros w byłgaro-jugoslawskite otnoszenija (1944-1952), Sofija 2004, s. 262. Natomiast Kardelj wskazał, że podpisany w Bled Traktat pomiędzy Jugosławią i Bułgarią został przedłożony rządowi sowieckiemu. Wówczas ustalono, że nie będzie obowiązywał „na wieczne czasy”, a dwadzieścia lat. Mołotow musiał przyznać, że jest to prawda. Zob. M.Djilas, Rozmowy..., s. 150.

${ }^{82} \mathrm{~W}$ czasie spotkania sowiecko-bułgarsko-jugosłowiańskiego w dniu 10 lutego 1948 r. za nieposłuszeństwo Tity i błąd w jego polityce zagranicznej Stalin uznał zamiar wprowadzenia dywizji wojsk jugosłowiańskich do południowej Albanii w pobliżu Korczy (na początku 1948 r.) w celu zabezpieczenia jej południowej granicy w czasie intensywnych walk w Grecji. W drugiej połowie 1947 r. Kreml pracował nad przejęciem kontroli gospodarczej nad Albanią, stąd wniosek, że obecność wojsk jugosłowiańskich w tym kraju zagrażałaby sowieckim interesom w przejmowaniu nad Tiraną kontroli. Także za błąd Stalin uznał wypowiedź Dymitrowa na temat federacji, która została wydrukowana 28 stycznia 1948 r. w moskiewskiej „Prawdzie”. Zob. Cold War International History Project, Bulletin 10, Washington 1998, Report of Milovan Djilas about a secret Soviet-Bulgarian-Yugoslav meeting 10 February 1948, s. 129.

${ }^{83}$ Zob. na ten temat: Leonid Ia. Gibianskii, The Soviet Bloc and the Initial Stage of the Cold War: Archival Documents on Stalin's Meetings with Communist Leaders of Yugoslavia and Bulgaria, 1946-1948, Cold War International History Project, Bulletin 10, Washington 1998, s. 116.
} 
wspominał ten moment jako rozkaz do wykonania, bez dyskusji i konsultacji ${ }^{84}$. Było to bezwzględne zobowiązanie Belgradu, że bez wcześniejszych konsultacji z Moskwą nie będzie podejmować żadnych działań w zakresie polityki zagranicznej. Podobną umowę podpisał ZSRS z Bułgarią.

Należy stwierdzić, że Związek Sowiecki po drugiej wojnie światowej miał powody ku temu, aby ściśle współpracować z Jugosławią, która była innym krajom Europy ŚrodkowoWschodniej i Bałkanów stawiana za wzór do naśladowania. Wówczas interesy Stalina zbiegały się z interesami Tity. Jeszcze w 1947 r. Tito, będący do końca 1947 r. wiernym sojusznikiem Kremla, był sowieckiemu dyktatorowi potrzebny do szybkiej stalinizacji regionu. Krytyka wobec Jugosławii nastąpiła dopiero w 1948 r., gdy Związek Sowiecki ustanowił ściślejszą kontrolę nad Europą Środkowo-Wschodnią i Bałkanami, a Stalin zaczął się obawiać, że Tito, cieszący się ogromnym poważaniem wśród komunistów, może swój autorytet wykorzystać do prowadzenia własnej polityki bałkańskiej. Wydarzenia z 1947 r. stanowiły jedynie pretekst do silniejszego podporządkowania sobie tak Belgradu, jak i Sofii na początku 1948 r. i trudno dostrzec w polityce Tity i Dymitrowa w 1947 r. „samowolę" lub brak współpracy.

\section{Bibliografia}

Dokumentacja archiwalna:

Narodowe Archiwum w Londynie (National Archives), NA, zespół FO 371.

Centralne Archiwum Państwowe Republiki Bułgarii w Sofii (Centralen Dyrżawen Archiw na Republika Byłgarija), CPA, fond: 146 .

Państwowe Archiwum Republiki Macedonii w Skopiu, (Državen Arhiv na Republika Makedonija), AM, fondovi: 1100 - MNR na FNRJ, CK KPM.

Dokumenty publikowane:

Cold War International History Project, Bulletin 10, Washington 1998, red. L.Ia. Gibianskii:

- Dok. I Soviet and Yugoslav Records of the Tito-Stalin Conversation of 27-28 May 1946;

- Dok. II Yugoslav Record of Conversation of I.V. Stalin and the Yugoslav Government Delegation Headed by J. Broz Tito, 27-28 May 1946, 120-127;

- Dok. III Report of Milovan Djilas about a secret Soviet-Bulgarian-Yugoslav meeting 10 February 1948, s. 128-134.

V. Dedijer, Dokumenti 1948. Kniga prva, Beograd 1979.

Foreign Relations of the U.S. - FRUS:

- FRUS 1945, vol. III, Yugoslav-Bulgarian Relations, Yalta;

- FRUS 1947, vol. IV, Eastern Europe; The Soviet Union;

- FRUS, 1947, vol. V, The Near East and Africa.

Istoriczeskite reszenija w Bled, „Politiczeski dwiżenija”, nr 9, Sofija 1947 g.

Makedonskijat wypros w byłgaro-jugoslawskite otnoszenija (1944-1952 g.), Sofija 2004.

${ }^{84}$ Treść całego dokumentu V. Dedijer, Dokumenti..., dok. 33, t. 1, s. 185, 186. Wypowiedź E. Kardelja, RTV Lubljana, „Naših pedeset let”, 26.maj-7.jul 1971. 
Pamiętniki:

Dimitrow G., Dniewnik (9 mart 1933-6 fewruari 1949), red. D. Sirkow, P. Boew, N. Awrejski, E. Kabakcziewa, Sofija 1997.

Djilas M., Rozmowy ze Stalinem, Warszawa 1991.

Monografie:

Angełow W., Chronika na edno nacionalno predatelstwo, Błagoewgrad 1999.

Bartoszewicz H., Polityka Zwiazku Sowieckiego wobec państw Europy Środkowo-Wschodniej w latach 1944-1948, Warszawa 1999.

Isusow M., Stalin i Bytgarija, Sofia 1991.

Čepreganov T., Stavot na Velika Britanija kon prašanjeto na Makedonija i jugoslovensko-bulgarskata federacija, Skopje 1980.

Janus J., Polska i Czechostowacja wobec Planu Marshalla, Kraków 2001.

Jotevski V., Nacionalnata afiranacija na Makedoncite vo Pirinskiot del na Makedonija 1944-1948, Skopje 1996.

Łałkow M., Ot nadeżda kym razoczarowanie. Idejata na federacijata w Bałkanski jugoiztok (19441948), Sofija 1994.

Kastory A., Mocarstwa wobec kryzysów w europejskich krajach sowieckiej strefy wplywów 1948 1968, Kraków 2015.

Kastory A., Jugostawia w polityce Stanów Zjednoczonych, Wielkiej Brytanii i Zwiqzku Sowieckiego 1948-1956, Kraków 2018.

Kiselinovski S., Egejskiot del na Makedonija (1913-1989), Skopje 1990.

Nešović S., Bledski sporazummi. Tito-Dimitrov (1947), Zagreb 1979.

Panajotow L., Paleszutski K., Miczew D., Makedonskijat wypros i bytgaro-jugoslawskite otnoszenija. Istorija, archeologija, kraeznanie, Sofija 1991.

Stawowy-Kawka I., Historia Macedonii, Warszawa-Wrocław-Kraków 2000.

Walkiewicz W., Stosunki bułgarsko-jugostowiańskie 1941-1948. Uwarunkowania i implikacje, Warszawa 1988.

Zacharias M. J., Idee, utopie, rzeczywistość. Myśl polityczna Milovana Djilasa (1911-1995), Bydgoszcz 2015.

Znamierowska-Rak E., Federacja Stowian poludniowych w polityce Bułgarii po II wojnie światowej. Korzenie. Próby realizacji. Upadek, Warszawa 2005.

Żurek P., Stowenia pod rzqdami Tity (1945-1980). W cieniu Jugosławii, Kraków 2017.

Artykuły:

Békés C., Soviet Plans to Establish the Cominform in Early 1946: New Evidence from the Hungarian Archives, Cold War International History Project, Bulletin 10, Washington 1998.

Gibianskii L.Ia., The Soviet-Yugoslav Conflict and the Soviet Bloc, [w:] F. Gori, S. Pons, red., The Soviet Union and Europe in the Cold War, 1943-53, Palgrave Macmillan UK, 1996.

Gibianskii L. Ia., The Soviet Bloc and the Initial Stage of the Cold War: Archival Documents on Stalin's Meetings with Communist Leaders of Yugoslavia and Bulgaria, 1946-1948, [w:] Cold War International History Project, Bulletin 10, Washington 1998.

Stawowy-Kawka I., Powojenne koncepcje federacji jugosłowiańsko-bułgarskiej (1944-1948), Zeszyty Naukowe UJ. Seria Nauk Politycznych UJ, 1988, t. CMXXII, z. 34.

Stawowy-Kawka I., Stosunek III Międzynarodówki i bałkańskich partii komunistycznych do problemu narodowego w Macedonii, Zeszyty Naukowe UJ, Seria Nauk Politycznych, 1985, z. 25.

Znamierowska-Rakk E., „Apogeum” zbliżenia południowosłowiańskiego po II wojnie światowej. Porozumienie Butgarii i Jugosławii w 1947 r. (1 sierpnia w Bled oraz 27 listopada w Ewksinogradzie), Dzieje Najnowsze (2005), R. 367, z. 2. 
Znamierowska-Rakk E., Bułgarzy czy Macedończycy? Wokót spisu ludności w Macedonii Piryńskiej z grudnia 1946 r., Studia Środkowoeuropejskie i Bałkanistyczne, 2017, t. XXVI, s. 245-261.

Irena Stawowy-Kawka, prof. dr hab., kierownik Katedry Historii Współczesnej w Instytucie Nauk Politycznych i Stosunków Międzynarodowych UJ. W kręgu jej zainteresowań badawczych znajdują się zarówno współczesne transformacje polityczne zachodzące na Bałkanach, jak i problematyka gospodarcza państw bałkańskich w kontekście polityki wielkich mocarstw oraz wzajemne relacje między państwami bałkańskimi. Jest autorką prac omawiających procesy polityczne w Jugosławii i państwach powstałych po jej rozpadzie, a także w Albanii, Bułgarii, Rumunii i Grecji. Do najważniejszych nurtów jej pracy naukowej należą skomplikowane losy Macedonii i problem macedoński, ponadto mniejszości narodowe, etniczne i religijne na Bałkanach. 